Dunaetz, D. R. (2016). Submission or cooperation? Two competing approaches to conflict management in mission organizations. In E. Smither \& R. Scheuermann (Eds.), Controversies in mission: Theology, People, and Practice in the $21^{\text {st }}$ Century (pp. 121142). Pasadena, CA: William Carey Library.

Chapter 6

\title{
Submission or Cooperation? Two Competing Approaches to Conflict Management in Mission Organizations
}

\author{
David R. Dunaetz \\ Azusa Pacific University
}

\begin{abstract}
Interpersonal conflict among missionaries is a major factor contributing to missionary attrition. This paper examines two approaches to resolving conflict, one focusing on mandatory submission to authority and the other focusing on fostering cooperation between the parties in conflict. Both biblical and empirical evidence suggest that cooperation is usually the best option. Although the submission approach is often viewed as biblical, it represents a shallow understanding of the complete biblical picture and a naïve and overly optimistic view of human nature. The cooperation approach better incorporates the biblical principles of servant leadership, mutual submission, and seeking one another's interests. Empirical evidence suggests that organizations such as mission agencies may be more effective if they adopt an approach fostering cooperation as an organizational norm. Research on power and its abuse may be used to motivate missionaries to voluntarily limit their hierarchical power in order to better love and serve others. Viewing conflict as a decision making process can enable missionaries and mission organizations to more effectively find ways to minister and achieve their goals, including evangelism and church planting.
\end{abstract}




\section{Submission or Cooperation? Two Competing Approaches to Conflict Management in Mission Organizations}

Conflict between missionaries, often within the same organization, is one of the most difficult and common phenomena that missionaries must deal with (Hale 1995; Carter 1999; Hay et al. 2007). Experiencing opposition from a team member in a difficult ministry context, may be extremely painful. Rather than receiving support from one of the few people who should understand the missionary, he or she may feel condemned, misunderstood, or the target of misplaced hostility. Such conflicts often slow down the work to which both parties feel called to (Dunaetz 2010a) and, even worse, may dishonor God who calls Christians to love one another as a sign of their discipleship (John 13:35) and who condemns fighting among Christians as a form of hatred toward him (James 4:1-10). It is a significant source of missionary attrition (Global Mapping International 2009) and may have long lasting negative consequences on a missionary's emotional health, physical health, and career (Tanner et al. 2012a; Tanner et al. 2012b; Romanov et al. 1996).

Because the consequences of conflict can be devastating, most Christians desire to resolve conflict in order to limit the damage it causes. Two competing paradigms can be observed in Christian contexts. The first paradigm, which focuses on the subordinate's need to obey authority, can be identified as the Submission Paradigm. This approach argues that the best way to resolve conflict is to submit to Godordained authorities. The second paradigm, which focuses on finding a solution which responds to both parties' concerns, can be identified as the Cooperation Paradigm. This approach argues that the best solution to a conflict is found by negotiating a solution that responds to the God- 
honoring interests of both parties. This study will examine the reasons for and against each approach and will argue that the cooperation model is the superior paradigm for dealing with missionary conflict.

\section{Two Paradigms of Conflict Management}

We will begin by summarizing these two paradigms of conflict management. Undoubtedly the actual approaches to conflict used by missionaries are much more diverse, but we will limit the discussion to two global approaches that could be considered opposite poles of a spectrum.

\section{The Submission Paradigm}

On Being a Missionary by Thomas Hale ${ }^{1}$ (1995) can serve as a source for a description of the Submission Paradigm to conflict management. He argues that the effective functioning of a team requires "that the team members submit to their leader, regardless of his qualities" (p. 219) and that the purpose of authority is to "mediate God's will in the Christian community" (p. 231) so "if one has a problem submitting to authority, his problem is basically with God" (p. 231). This means that, when a missionary finds himself or herself in a conflict, it is God's will for him or her to submit to whomever has authority. "All Christians are commanded to submit to authority over them, up to the point where that authority forces them to violate Scripture" (p. 231). Hale argues that missionaries must continue to submit even when "mission authorities may themselves unknowingly violate Scripture in the exercise of their duties, but that is a different matter; that does not give a worker license to disobey or rebel against their authority" ( $p$. 231). In unfortunate situations, depending on the motives that would cause an authority to unknowingly sin, this could mean a missionary

\footnotetext{
${ }^{1}$ Although this book is chosen to represent the point of view that I argue against, Thomas Hale (1995) has much to say that is beneficial to missionary candidates preparing to leave for the field and for young missionaries. The critiques in this paper are only of his view on authority and conflict, not of him or his ministry that the Lord has richly blessed.
} 
should continue to submit when faced with belittling, condescending insults, outbursts of anger, or other types of abuse, including physical or sexual abuse.

A key assumption of the Submission Paradigm is that people who hold power know the will of God for people who are under their authority, even when the authority makes a decision that a subordinate considers unwise or abusive. "Submitting to such decisions is the only sure way we have of ultimately knowing what God's will is. . . . We need to start out with the attitude of accepting our leaders' decisions as from God. . . . We need, first of all, to tell God that we will submit to anything the leadership says, and then trust him with the outcome" (Hale, 1995, p. 233).

Hale (1995) admonishes the missionary to not be afraid of submitting to authority: "Remember, your leaders are kindly disposed to those under them. . . . Submit to your leader's decision and let God cover the consequences. That is the only scriptural option you have" (p. 233). The key verse for this position is Hebrews 13:17, "Have confidence in your leaders and submit to their authority" (NIV). For Hale, if a person is not willing to submit, he or she is not fit to be a missionary. "We must state clearly: willingness to submit to authority is indispensable to a successful missionary career. The person who is not prepared to submit willingly to the decisions of his leaders should not come to the mission field" (p. 233).

The origin of much of this type of authoritarianism (Adorno 1950; Gabennesch 1972) in modern evangelicalism can be traced back to Bill Gothard's Institute of Basic Youth Conflicts seminar (Gothard 1975b) which was very influential in the 1970s. Gothard continued to be a leader within evangelicalism until he resigned in 2014 from his organization when faced with accusations of sexually abusing numerous young female employees (Pulliam 2014; Recovering Grace 2015). Gothard argued that the purposes for authority were to help a person grow in wisdom and character, to be protected from temptation, and to receive direction in life (Gothard 1975a, p. 1). Disobeying authority results in permanent damage by limiting our potential to be used by God (Gothard 1975a, p. 9). Thus to resist the chain of authority in Christian 
organizations is to resist God, even if the authority's behavior, wisdom, or motives are questionable. Gothard's Advanced Seminar argued that obeying authority is the means by which a person discovers God's will and that "as long as you are under God-given authority, nothing can happen to you that God does not design for your ultimate good" (Gothard 1986, p. 297). This has far reaching consequences. For example, Gothard taught that people who are sexually abused by people in authority should question if they were the source of temptation, repent if they were, and not see themselves as victims, but as having the opportunity to "become mighty in spirit," forgiving the offenders and letting God take care of them (Gothard n.d.). If inappropriate behavior in Christian leaders needs to be addressed, "we must come as a learner and as their servant. We must appeal to them on the basis of what is best for them, not what is offending us." (Gothard 1976, p. 22).

Thus in the submission approach to conflict management in mission organizations, the person lower in hierarchical power is responsible to obey the person with greater power. There is little room for discussion and the threat of being removed from ministry is real.

\section{The Cooperation Paradigm}

In contrast to the Submission Paradigm, the Cooperation Paradigm to conflict management views conflict as an opportunity to find solutions to problems that respond to the interests and desires of both parties. "Do not merely look out for your own personal interests, but also for the interests of others" (Phil. 2:4, NASB). The idea of submission is not absent from this approach, but rather than a superior requiring the submission of a subordinate, the two are to "be subject to one another in the fear of Christ." (Eph. 5:21, NASB). Rather than demanding or expecting obedience, rather than lording it over a subordinate, "If anyone wants to be first, he shall be last of all and servant of all" (Mark 9:35, NASB; being a servant is a major leadership theme in the New Testament, cf. Matt. 20:25-27, I Pet. 5:2-3).

In the social sciences, the Cooperation Paradigm is described in the dual interest model of conflict resolution (Rubin et al. 1994; Pruitt \& Carnevale 1993; Rahim 2001). This model assumes that conflict occurs 
when two parties have interests (concerns or desires) that at least one party perceives as being incompatible. For example, within a church planting team, one missionary may want the young church to start a new evangelistic activity and another might want to work on discipling and consolidating the initial group of believers which has started to meet together. The first missionary might believe that the group will lose its momentum without a new emphasis on evangelism, while the second missionary might believe that burnout is inevitable if he and the young believers feel they need to be involved in another program. Thus the first missionary may see the other missionary's concern for stability as incompatible with his own desire for growth. This perceived incompatibility of goals or interests sets the stage for a conflict between the two missionaries.

Furthermore, each missionary may have a low or high concern for his own interests and a low or high concern for the interests of the other missionary. The combination of levels of concern will predict to a great degree the conflict resolution strategy that each party will choose (de Dreu et al. 2000; Rahim 2001). These strategies are illustrated in Figure 1. If one person is more concerned about the other's goals (e.g., he or she is more concerned about the relationship) than his or her own goals, he or she will adopt a strategy of accommodation in response to the conflict. In the opposite situation, when a person is primarily concerned about his or her own goals rather than those of the other person, he or she will adopt a strategy of competition to try to achieve them, which will typically occur if he or she has more power than the other party; this strategy is characterized by the use of threat or force. If a person is not especially concerned about either party's goals, he or she will tend to adopt a strategy of avoidance to limit the likelihood that the conflict damages the existing status quo. Finally, if a person is concerned about both his or her own goals and those of the other party, the person will try to adopt a strategy of cooperation which might include dialogue, negotiation, or persuasion; this strategy is likely to be successful if the two parties are willing to generate a large number of possible solutions to the conflict in order to find that which would be optimal. 


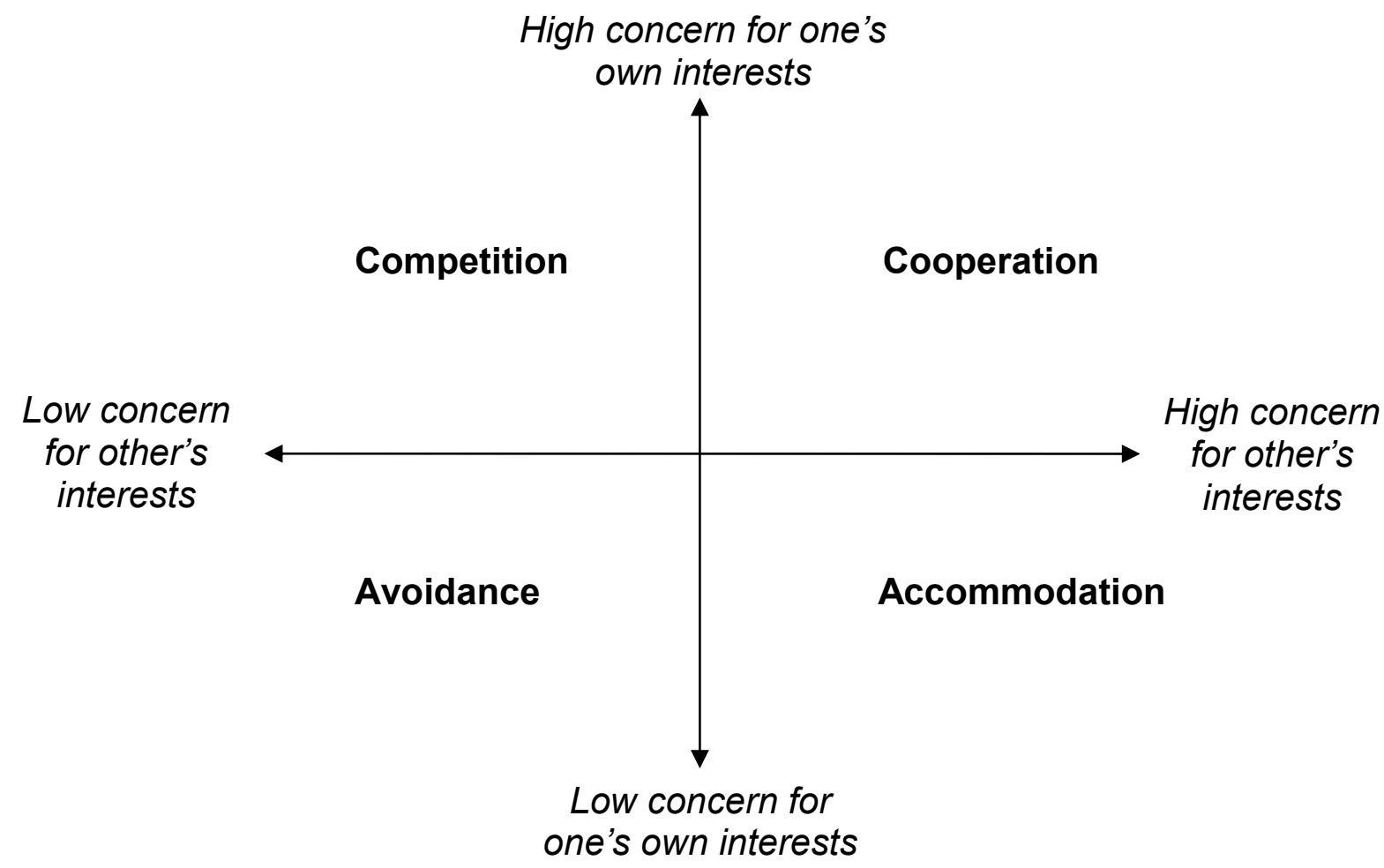

Figure 1. The Dual Concern Model of Conflict Resolution (Pruitt \& Kim 2004; Dunaetz 2011a; Wilmot \& Hocker 2001).

In our example of the two missionaries, if neither missionary is very concerned about preventing burnout or losing momentum, they are both likely to avoid discussing the topic; the cost of an emotionally draining and relationship damaging conflict will be too high. If the missionary who is concerned about losing momentum is more concerned about his relationship with the other missionary, this first missionary may accommodate the missionary who is concerned about burnout and let him have his way. However if the missionary is more concerned about losing momentum than damaging his relationship with the other missionary, he may willingly enter into combat with the other missionary to determine whose strategy will be adopted. However, if the missionary is concerned not just about his own interests (continuing the momentum), but is also concerned about the interests of the other missionary (preventing burnout), a situation which typically occurs when the two parties are trying to act in loving ways, he will try to 
cooperate with the other missionary to find a solution that will allow both parties to achieve their goals. Such a solution might include one missionary focusing on discipling a group of young believers and the other missionary continuing to organize evangelistic activities without applying pressure on the believers in the other missionary's discipleship group to participate.

If one missionary choses a competition strategy and the other an accommodation strategy, there will be no conflict; the interests of the missionary choosing competition will prevail. However, if both missionaries choose to compete, the missionary with more power will win and his interests will prevail. In the Submission Paradigm of conflict management, these two ways of resolving conflict are considered normal. The missionary lower in hierarchy is expected to voluntarily submit to the superior missionary. If he chooses to not do so, he can expect the other missionary to use his power to prevail. However, in the Cooperation Paradigm of conflict management, both missionaries are to avoid competing and seeking to have only their concerns addressed, but are to cooperate and find a solution that responds to both of their concerns. When a power differential exists between the missionaries, the more powerful missionary is expected to not use his power to force his will upon the other missionary; he is expected to empower the other missionary so that they can work together to find an optimal solution, viewing the conflict as a problem to be solved as brothers and sisters in Christ rather than a case of spiritual rebellion.

An optimal solution to a problem is typically found through the brainstorming of many, many possible solutions accompanied by discussion and negotiation concerning the best to choose (Greenberg 2005; Kuhn \& Poole 2000; Whyte 2000). If done in a spirit of mutual submission, each party will be able to provide servant leadership to the conflict resolution process in order to ensure that the other's concerns will be addressed (Greenleaf 1977).

\section{Critiques of the Two Paradigms}

The Submission Paradigm focuses on the necessity of missionaries 
to obey those who are higher in the organizational hierarchy; conflicts are resolved by submitting to the person in authority. The cooperation paradigm focuses on the needs and concerns of both people who in conflict, regardless of their hierarchical status; conflict is resolved by both people working together to find a solution that responds to each person's interests and concerns. Both paradigms claim to be biblical and have been used by sincere Christians who wish to serve the Lord. We will examine the Scriptural basis for each, as well as empirical evidence concerning what we may expect as outcomes from each approach.

\section{Critique of the Submission Paradigm}

The strongest biblical argument for the Submission Paradigm is in Hebrews 13:7, "Obey your leaders and submit to them, for they keep watch over your souls as those who will give an account" (NASB). It should be noted that the text does not indicate that this is how God's will is revealed to someone in a subordinate position. It does, however, indicate that leaders will be held accountable for the use of their power. In the context, the author of Hebrews has made it clear that a priority for both leaders and followers in the church is "to live in peace with all" (Heb. 12:14, NASB). In the broader context of the New Testament, Jesus warned against using one's power to "lord over" those in subordinate positions but rather to use one's power to serve and set an example (Matt. 20:25-28, I Pet. 5:2-3). Submission is certainly a result of being led by the Spirit, a means of revering Christ, but Christians are called to mutual submission, not one Christian forcing his or her will upon another (Eph. 5:21).

In light of both the specific context of Heb. 13:7 and the general context of the New Testament, the author of Hebrews would undoubtedly expect differences of opinion in the church or perceptions of interference to be dealt with constructively, with mutual respect being shown, in order that those in conflict may find a jointly acceptable, even beneficial, solution that enables them to live in peace with one another. Forcing the weaker person to submit to the more powerful person's authority, or expecting the weaker person to not have a voice in a decision that concerns him or her, is more like a sin for which the power 
holder would be held accountable than a strategy for godly leadership.

Understanding the Effects of Power. One of the underlying assumptions of the Submission Paradigm is that the power holders will use their power in a godly and Spirit-led way, depending on the Lord to provide the necessary checks and balances. Although some Christian leaders may use power this way, it is, unfortunately, not always the case. The experiences of the young women who worked for Bill Gothard or the pastoral staff working at Mars Hill Church serve as contemporary warnings that even the most trusted, respected, and influential Christian leaders may abuse their power in very destructive ways (Recovering Grace 2015; Tertin 2015). But how often does power lead to abuse? To what degree is Lord Acton's dictum true that "Power tends to corrupt, and absolute power corrupts absolutely" (Dalberg-Acton 1907)?

Christians are not alone in wanting answers to these questions. A number of research psychologists have sought to understand the effects of power. To begin to understand the effects of power, which can be defined as the ability to influence others, it is important to note that there are various types of power. A schema created by French and Raven (1960) describing five bases of power is still relevant for today. Reward Power is the ability to provide a material or non-material reward. In a mission organization, this might be a favorable ministry location or public recognition for one's work. Coercive power is its opposite; it is the ability to provide a material or non-material punishment, which acts as a threat. Examples in mission organizations would include the ability to refuse a reimbursement request or the power to demand that a missionary resign. Legitimate power comes from culturally agreed upon lines of authority. When one joins an organization, one agrees to respect the decision making processes that are in place. Referent power comes from a person liking, admiring, or appreciating the power holder. Helpfulness, celebrity, beauty, warmth, and caring are all associated with referent power. Expert power comes from competence and expertise in some valued domain. A missionary may have expert power due to his or her knowledge of the local culture, church planting strategies, or the Bible.

In organizations, including missionary organizations, these five 
power bases may be classified into two groups, position power and personal power (Northouse 2013). Position power comes from one's position or office that is assigned by those higher in an organization's hierarchy. Position power includes both reward and coercive power, as well as legitimate power. It is independent of the person and can be transferred to another member of the organization if the organizational hierarchy chooses to do so. In the Submission Paradigm, position power determines who is supposed to submit and who has the right to demand submission. In contrast, personal power comes from personal characteristics of an individual which cannot easily be separated from him or her or transmitted to others by an administrative decision. Personal power includes referent power and expert power.

Personal power typically does not cause as many problems of abuse as position power does in organizations. Certainly a person might be attractive and charming and use his or her referent power in a hurtful way. Similarly expert power may be used to actively pursue evil. However, in Christian contexts, referent power is most commonly associated with love for others (John 15:9-17, I Cor. 13:1-13) and expert power is associated with wisdom and knowledge (Prov. 1:8-4:27, cf. Ex. 31:3-4). In contrast, position power (the focus of the Submission Paradigm) is easily abused. A series of experiments by the social psychologist David Kipnis of Temple University has shown how readily positional power is abused (Kipnis 1976; Kipnis 1972; Kipnis 1984).

Kipnis found that having position power, especially coercive power, changes the power holder's view of self and of others with less power. Self is evaluated as being more important and more deserving, while others are evaluated as being less important and less worthy of respect. In a typical experiment (Kipnis 1972), volunteers were primed to think of themselves as being powerful by arbitrarily being designated as managers (versus employees) in an experiment (legitimate power). Sometimes this power was increased by giving them coercive power, such as the ability to reduce the employee's wages or to fire the employees, or by giving them reward power, such as the ability to give raises or bonuses to employees.

There are several reasons that people who are assigned position 
power may have an elevated sense of self-worth. The power holders may feel the need to justify their power over other people (Kipnis 1976). Since they have the power to punish or reward others, this must mean that their opinions and beliefs are superior to those of their subordinates. A missionary who is put in power over other missionaries will be tempted to justify such a power differential by concluding that he is more worthy of this position than those over whom he has power.

A second reason that power holders have a high view of themselves (relative to their subordinates) is because they fairly continuously receive compliments and flattery from those around them (Kipnis \& Vanderveer 1971; Kipnis 1972). Because flattery is a relatively effective way to gain the goodwill of power holders (Westphal \& Stern 2007; Gordon 1996), it occurs quite frequently in organizational settings, including mission organizations. When power holders continuously hear how good they are and how wonderful their work is, they are more likely to start believing in their superiority than if they did not hear the flattery. In addition, subordinates who do not verbally acknowledge the power holder's superiority are likely to be evaluated negatively because the power holder may feel that these subordinates are incapable of seeing that which is so clear to others. Similarly, power holders start believing that they are especially worthy of controlling resources because of their superiority. They may see themselves as having more rights because of their superior abilities. This may enable them to justify immoral behavior. They may view their well-being as so much more important to the organization than the well-being of others that fits of anger, various forms of theft, and taking sexual liberties with their subordinates may be justified in their minds.

A consequence of this elevated view of self and devaluing of others, especially in power holders with the ability to punish subordinates, is less willingness to cooperate and compromise in order to resolve conflicts (Deutsch \& Krauss 1960; Kipnis 1976; Kipnis 1984). Power makes people more aggressive and less concerned about the relational consequences of this aggressivity. Power holders with the ability to punish subordinates tend to avoid developing much of a relationship with those whom they can punish (Fiedler 1967; Magee \& 
Smith 2013). For example, Kipnis (1972) found that $79 \%$ of people randomly assigned a high status position without the ability to punish a subordinate expressed an interest in meeting the person and having a coffee together. However, only $35 \%$ of the power holders who had the ability to punish were interested in meeting the person socially. Leaders with the power to punish may avoid socializing with subordinates because they believe that they would lose some of their power if they started friendships which would cause them to be less willing to use coercion on them. Alternately, they may avoid socialization because they know they would feel bad about punishing someone who had become their friend. They may fear losing status if they were to fraternize with a person potentially worthy of punishment. Thus forcing, coercion, or demanding obedience becomes the normal way of resolving conflicts, rather than cooperation.

Thus the abuse of power in Christian organizations with leaders using the Submission Paradigm should not be surprising. Such an approach to conflict resolution sets the stage for lording over the less powerful, abusing them, keeping them at an emotional distance, and devaluing them and their work. When conflicts occur with a missionary leader using the Submission Paradigm, the junior missionary is left feeling unworthy and unheard. This approach provides discouragement rather than encouragement, contributing to ineffective missionary teams (Dunaetz 2010a), a sense of being unjustly treated (Dunaetz 2010c), and even missionary attrition (Hay et al. 2007; Global Mapping International 2009).

\section{Critique of the Cooperation Paradigm}

Although the Cooperation Paradigm of conflict resolution looks very attractive from a biblical point of view with its emphasis on responding to both parties' interests (Phil. 2:4), servant leadership (Matt. 20:26), optimal solutions (Prov. 15:22), and healthy relationships (Heb. 12:14), there are several costs and dangers involved. Managing conflict with the Cooperation Paradigm is time consuming and mentally demanding. In extreme cases, it can also distract from the mission of the organization. 
Whereas the Submission Paradigm can result in quick decisions requiring little reflection or communication, the Cooperation Paradigm by nature requires much time and effort. It seeks to find solutions to problems other than the solutions that might be immediately available to the missionary with hierarchical authority. One of the fundamental requirements to finding optimal solutions to a problem in organizations is creating a set of possible solutions from which to choose (Greenberg 2005; Whyte 2000). Creating such a set of alternatives may require much mental effort and time.

This might be especially difficult for Christian leaders who do not feel the need to evaluate strategies for their effectiveness or want to compare the merits of one alternative over another. Individuals differ in their need for cognition, a personality trait characterized by the "tendency to engage in and enjoy effortful cognitive activity." (Cacioppo et al. 1996, p. 197). Some people are motivated to think through problems, come up with alternatives, and evaluate the merits of each, while others feel less internal pressure to do so. People high in need for cognition might experience more success in cognitive activities and thus are willing to expend more effort in creating and evaluating activities. People low in the need for cognition may not receive much satisfaction for exerting the effort necessary for effective problem solving (Cacioppo et al. 1996; Dunaetz 2011b). Thus mission leaders with a low need for cognition may find the Cooperation Paradigm exasperating and the Submission Paradigm especially attractive.

Another ability that influences the amount of effort needed to function within the Cooperation Paradigm is perspective taking, the ability to see the issues from the other person's cognitive and emotional point of view (Johnson 1975; Johnson et al. 2000). This ability enables a person to see the value in alternative solutions that the other person proposes while they discuss the issues. Typically it is expressed as paraphrasing what the other person has said to receive feedback indicating correct or incorrect comprehension of the others point of view, or as imagining the other person's emotional response to a proposal. This is typically a skill that is developed during childhood and adolescence (Sandy \& Cochran 2000). Some people have greater 
perspective taking skills than others. Those in authority who find it difficult to take another person's perspective will view the Cooperation Perspective as more difficult and less attractive.

Nevertheless, mission leaders with limited need for cognition or perspective taking skills may still find that the Cooperation Paradigm is worth the effort it requires because of its biblical justification. Mission executives may notice that field leaders may not be attracted to the Cooperation Paradigm and prefer requiring submission from those under their authority. If this is a possible scenario, mission executives need to make sure that a conflict management system is firmly in place in the mission organization (Costantino \& Merchant 1996). Such conflict management systems typically provide mediation whenever one party requests it. In order for the system to be effective when there is a hierarchical power differential between the missionaries, it must be designed so that

1. The more powerful party cannot deny a request for mediation.

2. The system must provide a mutually acceptable mediator who is perceived as trustworthy and neutral by both parties.

3. The system is not simply created to reduce liability in case of conflict; the use of the system must be promoted by all levels of authority within the organization.

Such a system may be implemented even in cases of long-distance separation of mission members when the determination exists to create constructive, cooperative solutions to missionary conflict (Dunaetz 2010b).

Another critique of the Cooperation Paradigm is that it could distract from the mission of the organization. Here is an extreme case to illustrate this point. Suppose the mission of an organization is evangelism and church planting but a junior missionary develops a passion for animal rights. In this case, a cooperative solution to a conflict which might occur concerning the placement of a junior missionary would be to assign him to a ministry of evangelism and church planting among animal rights activists. However, if the junior missionary is no longer interested in evangelism and church planting, such a placement would be ineffective and inappropriate. In fact, any 
cooperative solution might divert resources from the organization's mission. If the organization provides resources for the junior missionary to pursue his interests, a phenomena known as mission shift occurs. No longer is the organization's mission limited to evangelism and church planting, but it would also now include the defense of animal rights. In cases such as this, to prevent mission shift, mission leadership might rightfully conclude that cooperation is not appropriate; requesting the resignation of the junior missionary might be more appropriate. Similarly, agreement to the organization's doctrinal statement or other foundational documents might also be non-negotiable; cooperation which involves compromise with what the organization believes is God's will for it would not appropriate.

However, these types of situations where cooperation presents a danger are most likely relatively rare. It is far more likely that selfserving biases of power holders would motivate them to believe their interests are God's will because they feel threatened by a subordinate (Ross 1977; Ross et al. 1977). The tall poppy effect occurs when high achievers, especially those without hierarchical power, are cut down, resulting in positive emotional reactions in those who no longer fear being compared to them (Feather 1989). In Christian circles, a popular way of cutting down someone is to declare their interests outside the will of God. If the Submission Paradigm is being used, this would include any interest that the hierarchical superior opposes. Power holders who have doubts about their own competence or have low self-esteem are especially likely to be motivated to seek the downfall of high achievers and thus make the appropriate accusations (Feather 1991; Rucker \& Petty 2003; Rucker \& Pratkanis 2001). Once again, the best way to prevent such abuse is to have in place a mediator-based conflict management system which the mission organization's leaders encourage the less powerful members to use (Costantino \& Merchant 1996; Dunaetz 2010b).

Understanding the Effects of Cooperation. The most obvious effect of cooperation in organizations is an increase in the quality of group decisions (Kuhn \& Poole 2000). When faced with a problem, considering a greater number of possible responses enables a group to 
find better solutions than when it only considers one or two options. This effect not only occurs in small groups and teams, but also in organizations as a whole (Rahim 2001; Tjosvold 1991) when the organizational culture promotes healthy conflict resolution cooperation. Additional research (Jehn 1997b; Greer \& Jehn 2007; de Dreu \& Weingart 2003) has found that for conflict to be most productive, the conflict should focus on the task at hand. When the conflict becomes personal, it quickly becomes emotional (Dunaetz 2014; Jehn 1997a). Negative emotions prevent constructive dialogue and reduce the ability to find the optimal solution. Therefore, cooperation is most likely to occur when both parties are committed to focusing on a single issue related to accomplishing the goals of the organization, and are willing to avoid criticizing each other personally, whether it be one's behavior, background, or values.

\section{Conclusion}

We have looked at two approaches to conflict management in mission organizations, the Submission Paradigm and the Cooperation Paradigm. Some missionaries will prefer operating under the Submission Paradigm, but this paper has argued for the use of the Cooperation Paradigm because of its congruency with the Christian values of love, mutual understanding, servant leadership, and mutual submission to seek the well-being of others. The dangers of abusing the power associated with a strict hierarchy of authority in the Submission Paradigm are great, and have often resulted in abuses that have nothing to do with the gospel. Mission organizations which promote the Cooperation Paradigm will thus create an atmosphere that is safe for missionaries, enables the organization to better achieve its goals, and is in harmony with biblical values and principles. 


\section{References}

Adorno, TW 1950. The Authoritarian Personality, New York, NY, Harper.

Cacioppo, JT, Petty, RE, Feinstein, JA \& Jarvis, WBG 1996.

Dispositional differences in cognitive motivation: The life and times of individuals varying in need for cognition. Psychological Bulletin, 119, 197-253.

Carter, J 1999. Missionary stressors and implications for care. Journal of Psychology and Theology, 27, 171-180.

Costantino, CA \& Merchant, CS 1996. Designing Conflict Management Systems, San Francisco, CA, Jossey-Bass.

Dalberg-Acton, JEE 1907. Letter to Bishop Mandell Creighton, dated April 5, 1887. In: Figgis, JN \& Laurence, RV (eds.) Historical Essays and Studies. London: Macmillan.

de Dreu, CKW \& Weingart, LR 2003. Task versus relationship conflict, team performance, and team member satisfaction: A meta-analysis. Journal of Applied Psychology, 88, 741-749.

de Dreu, CKW, Weingart, LR \& Kwon, S 2000. Influence of social motives on integrative negotiation: A meta-analytic review and test of two theories. Journal of Personality and Social Psychology, 78, 889-905.

Deutsch, M \& Krauss, RM 1960. The effect of threat upon interpersonal bargaining. The Journal of Abnormal and Social Psychology, 61, 181-189.

Dunaetz, DR 2010a. Good teams, bad teams: Under what conditions do missionary teams function effectively? Evangelical Missions Quarterly, 46, 442-449.

Dunaetz, DR 2010b. Long distance managerial intervention in overseas conflicts: Helping missionaries reframe conflict along multiple dimensions. Missiology, 38, 281-294.

Dunaetz, DR 2010c. Organizational Justice: Perceptions of Being Treated Fairly. In: Baker, D \& Hayward, D (eds.) Serving Jesus with Integrity: Ethics and accountability in mission. Pasadena, CA: William Carey Library. 
Dunaetz, DR 2011a. Personality and conflict style: Effects on membership duration in voluntary associations, Saarbrücken, Germany, Lambert Academic Press.

Dunaetz, DR 2011b. Understanding the Effects of Diversity in Mission from a Social Science Perspective. In: Moreau, AS \& Snodderly, B (eds.) Reflecting God's Glory Together: Diversity in Evangelical Mission. Pasadena, CA: William Carey Library.

Dunaetz, DR. 2014. The achievement of conflict-related goals leads to satisfaction with conflict outcomes. CGU Theses \& Dissertations. Paper 89. http://scholarship.claremont.edu/cgu_etd/89.

Feather, NT 1989. Attitudes towards the high achiever: The fall of the tall poppy. Australian Journal of Psychology, 41, 239-267.

Feather, NT 1991. Attitudes towards the high achiever: Effects of perceiver's own level of competence. Australian Journal of Psychology, 43, 121-124.

Fiedler, FE 1967. A theory of leadership effectiveness, New York, NY, McGraw Hill.

French, JRP \& Raven, B 1960. The bases of social power. In:

Cartwright, D \& Zander, A (eds.) Group Dynamics. New York, NY: Harper and Row.

Gabennesch, H 1972. Authoritarianism as world view. American Journal of Sociology, 77, 857-875.

Global Mapping International. 2009. The Engage! Study Executive Summary. Available:

http://www.gmi.org/files/9613/6096/6908/Engage_Executive_Sum mary.pdf.

Gordon, RA 1996. Impact of ingratiation on judgments and evaluations: A meta-analytic investigation. Journal of Personality and Social Psychology, 71, 54-70.

Gothard, B 1975a. Authority and Responsibility. In: Gothard, B (ed.) Institute in basic youth conflicts: Research in principles of life. Oak Brook, IL: Institute in Basic Youth Conflicts.

Gothard, B 1975b. Institute in basic youth conflicts: Research in principles of life, Oak Brook, IL, Institute in Basic Youth Conflicts. 
Gothard, B 1976. Instructions for Our Most Important Battle, Oak Brook, IL, Institute in Basic Youth Conflicts.

Gothard, B 1986. Advanced Seminar Textbook. Oak Brook, IL: Institute in Basic Life Principles.

Gothard, B n.d. Counseling Sexual Abuse, Oak Brook, IL, Advanced Training Institute of America.

Greenberg, J 2005. Managing behavior in organizations, Upper Saddle River, NJ, Prentice Hall.

Greenleaf, RK 1977. Servant Leadership: A Journey into the Nature of Legitimate Power and Greatness, New York, NY, Paulist Press.

Greer, LL \& Jehn, KA 2007. The pivotal role of negative affect in understanding the effects of process conflict on group performance. Research on managing groups and teams, 10, 23-45.

Hale, T 1995. On being a missionary, Pasadena, CA, William Carey Library.

Hay, R, Lim, V, Blocher, D, Ketelaar, J \& Hay, S 2007. Worth Keeping: Global Perspectives on Best Practice in Missionary Retention, Pasadena, CA, William Carey Library.

Jehn, KA 1997a. Affective and Cognitive Conflict in Work Groups: Increasing Performance Through Value-Based Intragroup Conflict. In: de Dreu, CKW \& Van de Vliert, E (eds.) Using Conflict in Organizations. Thousand Oaks, CA: Sage Publications.

Jehn, KA 1997b. A Quantitative Analysis of Conflict Types and Dimensions in Organizational Groups. Administrative Science Quarterly, 42, 530-557.

Johnson, DW 1975. Cooperativeness and social perspective taking. Journal of Personality and Social Psychology, 31, 241-244. Johnson, DW, Johnson, RT \& Tjosvold, D 2000. Constructive Controversy. In: Deutsch, M \& Coleman, PT (eds.) The Handbook of Conflict Resolution. San Francisco, CA: Jossey-Bass.

Kipnis, D 1972. Does power corrupt? Journal of Personality and Social Psychology, 24, 33-41.

Kipnis, D 1976. The powerholders, Chicago, IL, University of Chicago Press 
Kipnis, D 1984. The use of power in organizations and in interpersonal settings. Applied Social Psychology Annual, 5, 179-210.

Kipnis, D \& Vanderveer, R 1971. Ingratiation and the use of power. Journal of Personality and Social Psychology, 17, 280-286.

Kuhn, T \& Poole, MS 2000. Do conflict management styles affect group decision making? Human Communication Research, 26, 558-590.

Magee, JC \& Smith, PK 2013. The social distance theory of power. Personality and Social Psychology Review, 17, 158-186.

Northouse, PG 2013. Leadership: Theory and Practice, Los Angeles, CA, Sage.

Pruitt, DG \& Carnevale, PJ 1993. Negotiation in social conflict, Pacific Grove, CA, Brooks Cole

Pruitt, DG \& Kim, SH 2004. Social Conflict: Escalation, Stalemate, and Settlement, Boston, MA, McGraw Hill.

Pulliam, B. 2014. Conservative leader Bill Gothard resigns following abuse allegations. Washington Post, March 7.

Rahim, MA 2001. Managing Conflict in Organizations, Westport, CT, Quorum Books.

Recovering Grace. 2015. A Gothard generation shines light on the teachings of IBLP and ATI [Online]. Available:

recoveringgrace.org.

Romanov, K, Appelberg, K, Honkasalo, M-L \& Koskenvuo, M 1996.

Recent interpersonal conflict at work and psychiatric morbidity: A prospective study of 15,530 employees aged 24-64. Journal of Psychosomatic Research, 40, 169-176.

Ross, L 1977. The intuitive psychologist and his shortcomings:

Distortions in the attribution process. In: Berkowitz, L (ed.) Cognitive Theories in Social Psychology: Papers from Advances in Experimental Social Psychology. New York, NY: Academic Press.

Ross, L, Greene, D \& House, P 1977. The false consensus effect: An egocentric bias in social perception and attribution processes. Journal of Experimental Social Psychology, 13, 279-301.

Rubin, JZ, Pruitt, DG \& Kim, SH 1994. Social Conflict: Escalation, Stalemate, and Settlement, New York, NY, McGraw-Hill. 
Rucker, DD \& Petty, RE 2003. Effects of accusations on the accuser: The moderating role of accuser culpability. Personality and Social Psychology Bulletin, 29, 1259-1271.

Rucker, DD \& Pratkanis, AR 2001. Projection as an interpersonal influence tactic: The effects of the pot calling the kettle black. Personality and Social Psychology Bulletin, 27, 1494-1507. Sandy, SV \& Cochran, KM 2000. The Development of Conflict Resolution Skills in Children. In: Deutsch, M \& Coleman, PT (eds.) The Handbook of Conflict Resolution: Theory and Practice. San Francisco, CA: Jossey-Bass.

Tanner, MN, Wherry, JN \& Zvonkovic, AM 2012a. Clergy who experience trauma as a result of forced termination. Journal of Religion and Health, 1-15.

Tanner, MN, Zvonkovic, AM \& Adams, C 2012b. Forced termination of American clergy: Its effects and connection to negative well-being. Review of Religious Research, 54, 1-17.

Tertin, B 2015. The Painful Lessons of Mars Hill: What Can We learn from the Collapse of Mark Driscoll's Church? Leadership Journal, $37(1), 18-22$.

Tjosvold, D 1991. The Conflict-Positive Organization, Reading, MA, Addison-Wesley.

Westphal, JD \& Stern, I 2007. Flattery will get you everywhere (especially if you are a male Caucasian): How ingratiation, boardroom behavior, and demographic minority status affect additional board appointments at US companies. Academy of Management Journal, 50, 267-288.

Whyte, G 2000. Make Good Decisions by Effectively Managing the Decision-Making Process. In: Locke, EA (ed.) The Blackwell Handbook of Principles of Organizational Behavior. Oxford, UK: Blackwell Publishers.

Wilmot, WW \& Hocker, JL 2001. Interpersonal Conflict, Boston, MA, McGraw Hill. 